\title{
Article \\ Erosion Rate of the Aliano Biancana Badlands Based on a 3D Multi-Temporal High-Resolution Survey and Implications for Wind-Driven Rain
}

\author{
Antonella Marsico*(D), Vincenzo De Santis and Domenico Capolongo \\ Dipartimento di Scienze della Terra e Geoambientali, Università degli Studi di Bari "Aldo Moro", via E. Orabona, \\ 70125 Bari, Italy; vincenzo.desantis@uniba.it (V.D.S.); domenico.capolongo@uniba.it (D.C.) \\ * Correspondence: antonella.marsico@uniba.it
}

check for updates

Citation: Marsico, A.; De Santis, V.; Capolongo, D. Erosion Rate of the Aliano Biancana Badlands Based on a 3D Multi-Temporal High-Resolution Survey and Implications for Wind-Driven Rain. Land 2021, 10, 828 https://doi.org/10.3390/ land10080828

\section{Academic Editors: Feliciana}

Licciardello, Damien Raclot, Armand Crabit and Rossano Ciampalini

Received: 22 June 2021

Accepted: 3 August 2021

Published: 7 August 2021

Publisher's Note: MDPI stays neutral with regard to jurisdictional claims in published maps and institutional affiliations.

Copyright: (c) 2021 by the authors. Licensee MDPI, Basel, Switzerland. This article is an open access article distributed under the terms and conditions of the Creative Commons Attribution (CC BY) license (https:// creativecommons.org/licenses/by/ $4.0 /)$.

\begin{abstract}
Biancana badlands are peculiar landforms in the Basilicata region of Italy resulting from the local combination of geological, geomorphological, and climatic settings. The evolution of badlands mainly depends on slope erosion, which is controlled by the angle, exposure, and vegetation of the slope and its interactions with insolation, rain, and wind. Multi-temporal, detailed, high-resolution surveys have led researchers to assess changes in slopes to investigate the spatial distributions of erosion and deposition and the influence of wind-driven rain (WDR). A comparison between two terrestrial laser scanner (TLS) point clouds surveyed during 2006 and 2016 fieldwork showed that the study area suffers from intense erosion that is not spatially uniform on all sides of biancane. By combining slope and exposure data and the cloud of difference (CoD), derived from a 3D model, we showed that all the steepest southern sides of biancane suffered the most intense erosion. Because splash and sheet erosion triggers sediment displacement, the analysis was also focused on the intensity and direction of WDR. We performed a real field experiment analysing erosion rates over 10 years in relation to daily and hourly wind data (direction and speed), and we found that frequent winds of moderate force, combined with moderate to heavy rainfall, contributed to the observed increase in soil erosion when combined with the insolation effect. Our results show how all the considered factors interact in a complex pattern to control the spatial distribution of erosion.
\end{abstract}

Keywords: biancane; badlands; 3D models; multitemporal comparison; erosion; wind-driven rain

\section{Introduction}

Badlands are landforms typical of semiarid regions, under a high runoff rate and a low vegetation cover [1,2]. These forms are extended in almost all of the Mediterranean basin, depending on the bedrock and soil properties [3-6]. In Italy, badlands landforms are widespread in almost all regions where there are Plio-Pleistocene marine sediments, composed of alternating beds of clay, marl-clay, silt clay, and silt outcrop [7-10]. The badlands forms are known as calanchi and biancane: calanchi are bare, steep slopes with a sharp drainage network affected by slope processes [11], and biancane are 10-20 m dome-shaped hills dissected by micro-rills or micro-pipes [12,13].

The badlands of Aliano, covering a central part of the Basilicata region in southern Italy (Figure 1), are dominated by biancane [13-15]. Several studies have investigated the processes that act on low-relief landscapes to originate the biancane landforms $[7,11,13,14]$ : they develop on reticular joint systems controlling the formation of rill networks, promoting the collapsed-pipe formations that generate block-like small hills with bare flanks and vegetated tops $[13,16]$. The erosion processes depend on the characteristics of the clay materials, both in the middle and at the base of slopes $[13,14]$. As a consequence, subsurface flows become the main erosion processes; pipe enlargement leads to pipe collapse and the consequential isolation of cones on slopes. Subsequently, overland flows become dominant since rilling is active on the dome flanks, reducing their sizes and rounding their shapes, 
then canalises in small gullies, forming residual conical domes of different morphologies after the pipes' roofs collapse $[7,10,16]$. In the lower topographic areas between domes, less concentrated surface flows and deposition promote vegetation cover and micropediment formation [12,13].

Even if the evolution of biancane is quite well known, their spatial continuous erosion rates are not easy to assess [17]. These rates are very important in terms of sediment (dis)connectivity on hillslopes and carbon dynamics [18,19]. In several studies, direct erosion measurements were made with pins placed in slightly accessible areas where piping was usually absent [8,20-23]. Indirect measurements can be calculated by comparing multi-temporal digital elevation models (DEMs) provided from digital stereopair photograms $[20,24]$ or, more recently, from lidar technology or unmanned aerial vehicle (UAV) photogrammetry [25-29]. Comparative analyses between two or more DEMs of the same area can highlight the slope areas affected by erosion or accumulation and provide an estimation of the spatially distributed erosion rates [24,28,29]. The systematic and random vertical errors in these studies have been assessed by measuring the elevation differences between DEMs and ground control points (GCPs), and these errors are usually of values on the order of centimetres $[23,24,27,30]$, which are acceptable when considering the metric ground level changes that occurred in the considered time span and the relatively large size of the surveyed areas. However, the vertical errors are strictly linked to the DEM resolutions. The choice of resolution is critical when using a DEM to study the spatial patterns of these processes, since erosion and deposition are spatially heterogeneous across hillslopes [31]. The DEM resolutions used in previous analyses ranges from a cell size of $5 \mathrm{~m} \mathrm{[20]} \mathrm{or} 2 \mathrm{~m} \mathrm{[24]} \mathrm{to} \mathrm{those} \mathrm{ranging} \mathrm{from} 5 \mathrm{~cm}$ to $15 \mathrm{~cm}$ for studies using a terrestrial laser scanner (TLS)- and structures from motion (SfM)-derived DEMs, respectively [27]. In general, TLS provides more precise detection and quantification of changes, whereas SfM DEMs are more appropriate to measure rates in wider areas [26-28].

Several studies have also analysed changes in hydrological catchments, quantifying the accumulated or eroded volumes and detecting the morphological processes acting on badlands $[22,24,27]$. In these studies, the factors acting on badland hillslopes, such as the slope angle, orientation, vegetation, rain, and wind, were identified; in fact, badlands are complex landscapes in which the interaction between different geomorphological processes is present [32].

The correlation determined between erosion and the slope angle shows that the steepest biancane sides experience major erosion due to the downward component of splash and sheet erosion, which is dominated by gravity [33]. Additionally, exposure affects the rate of erosion due to the dry and wet balances involved in sediment cohesion; the presence of soil on the top contributes to the maintenance of steeper slope angles; and vegetation can interfere with erosion processes [1]. Moreover, it has been suggested that rills and pipe erosion produce similar quantities of sediment per unit of runoff discharge under rainfall events [1,7]. Piccarreta et al. [14] showed how daily rainfall totals over $10 \mathrm{~mm}$ exceed the threshold for erosion occurrence, while rainfall amounts of $30 \mathrm{~mm}$ cause severe rill erosion and mass movements on slopes. However, research on hydrological and erosional contribution to badlands evolution has been conducted by rainfall field simulation [34] and references therein]. Recently, some studies have pointed out how the combined actions of rain and wind can accelerate erosion on slopes. The diversion of raindrops from the vertical direction is directly proportional to the wind speed, up to a wind speed of $6 \mathrm{~m} / \mathrm{s}$ (which is a value within the moderate breeze on the Beaufort scale [35]). For wind speeds greater than $6 \mathrm{~m} / \mathrm{s}$, the raindrop diversion angle slowly increases until the wind speed reaches $10 \mathrm{~m} / \mathrm{s}$, and then remains constant [36]. Wind-driven rain (WDR) has been investigated in several papers and is considered an important factor in soil erosion and runoff generation, particularly under the combined conditions of heavy rainfall with low to moderate winds [36-39]. According to Marzen et al. [38], WDR has a great impact on runoff generation and is a crucial factor for natural hazard risk assessments, since it can increase soil erosion. However, until now, all WDR studies have been carried out in 
laboratory experiments using wind tunnels, and it is difficult to assess the contribution of WDR to slope erosion under field conditions also taking into account the main direction of surface wind in different weather types [40].

We used multi-temporal surveys carried out by high-precision TLS technology to detect where topographic changes occur on biancane hillslopes. The detailed 3D model comparison led to assessment of the amount of changes, as erosion or deposition, and how the influence of the morphological setting, of rainfall, and main direction of WDR can affect changes on the surface.

\section{Materials and Methods}

\subsection{Study Area: Geological and Climate Data}

The study area is located in the well-known badlands of the Basilicata region near Aliano, Italy (Figure 1) on a south-facing hillslope of a monocline, and is approximately $10,000 \mathrm{~m}^{2}$. The area is situated between the central part of the Bradanic Trough and the Lucanian Apennines, and is in the north-eastern area of the Plio-Pleistocene Sant'Arcangelo Basin. The outcropping succession ranges from 500 to $900 \mathrm{~m}$ thick [41,42] and is mainly characterised by grey-blue marls, with rare beds of sands and shallow marine clays with middle-high plasticities. The sediments include minerals with high Na content minerals with the tendency to disperse rapidly when wetted [43].

The study area was affected by the uplift of the eastern margin of the Apennine chain during the Upper Pliocene and Pleistocene ages [43]. Starting in the Middle Pleistocene, rivers incised deep valleys that extended perpendicularly to the coast due to continuous regional uplift, climatic changes, and related sea-level movements [44-47], whereas erosion affected the hillslopes, exposing highly erodible clayey bedrock.

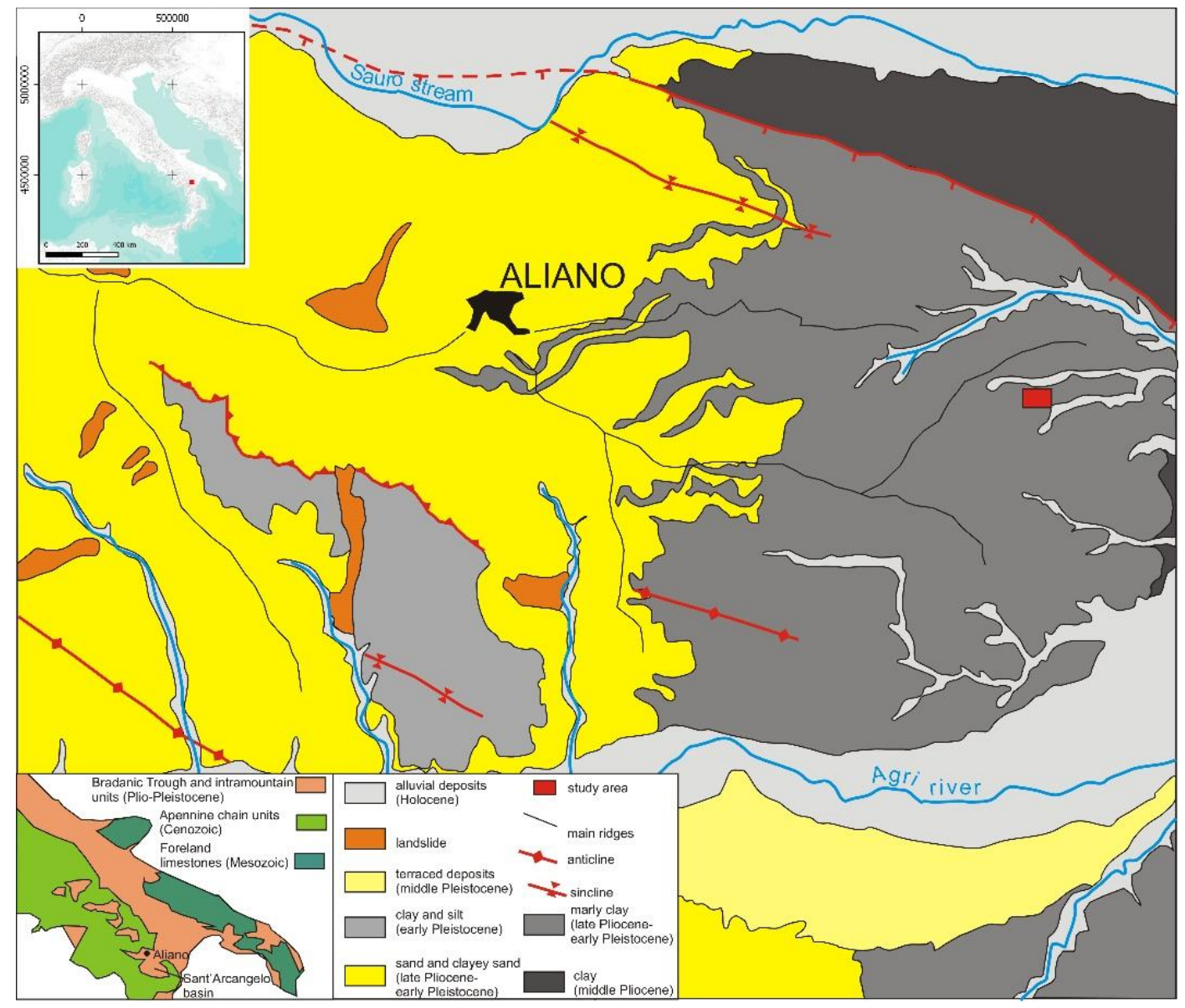

Figure 1. Geological setting of the Aliano area; the studied hillslope area is shown by the red rectangle. 
In the Aliano area, the topography is characterised by a simple NE-dipping monoclinal landscape $[13,14]$, with erosion features common to clayey-silty terrain exposed to the south [48]. The seasonal rainfall distribution, high relative relief, and nature of the bedrock have contributed to creating the biancane landscape (Figure 2a,b). In the study area, a high-density drainage network of small, inclined pipes in the middle part of the slope (Figure 2c) originates from a subsurface flow that causes collapses, and then isolates cones at the bases of the hillslopes (Figure 2d), where the overland flows prevail and the crust crumbles in small gullies that create residual cones [14]. A recent study [15] showed that the dome-shaped features are influenced by NW-SE strike-slip shear fractures and that structural discontinuities within the claystones are the main factors responsible for the gravity-driven mass movements and erosion processes.

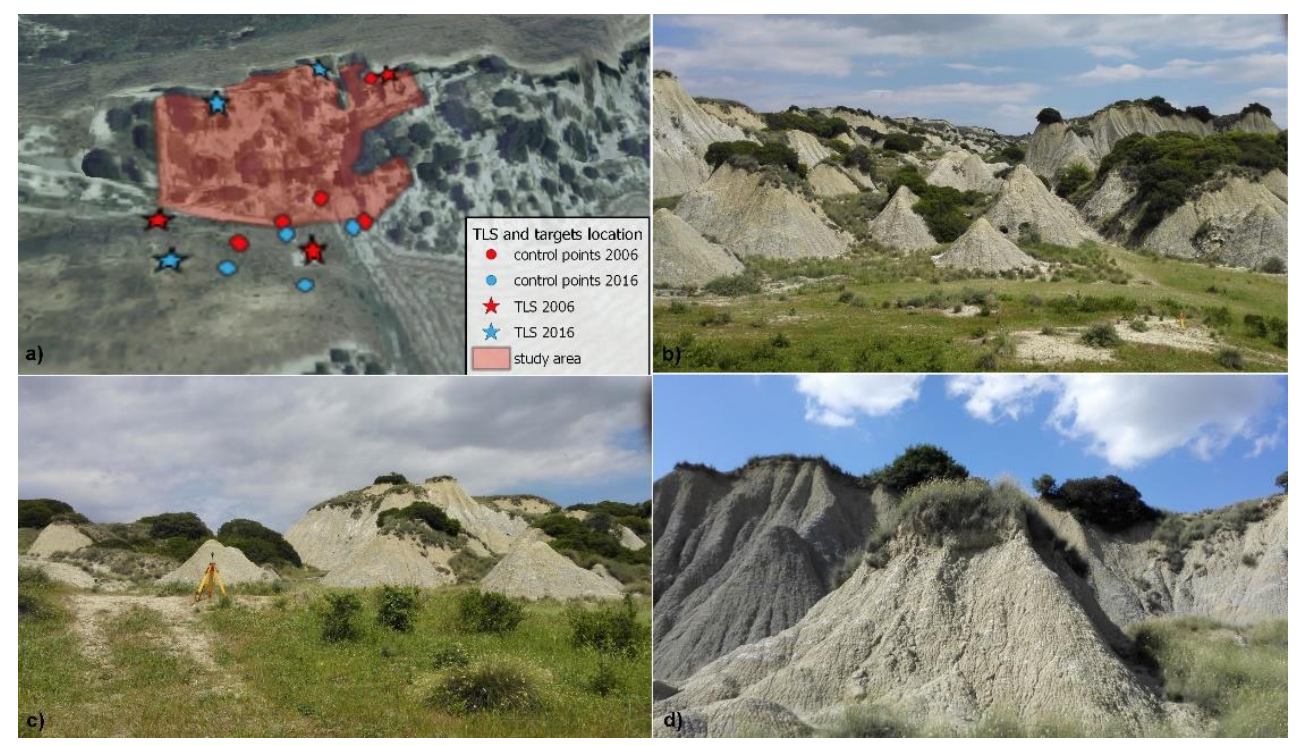

Figure 2. (a) 3D view of the study area and location of TLS and control points in both 2006 and 2016 surveys; (b) the surveyed biancana landscape characterised by isolated domes at the middle and at the base of the slope; (c) dome-shaped features at the base of a slope, showing one of the highest-resolution control points (targets) used to overlap the scans; (d) a typical dome-shaped feature with vegetation on its top; rills are visible on the slope.

This part of the Basilicata region enjoys the Mediterranean climate, characterised by warm, dry summers with a mean maximum summer temperature of approximately $25^{\circ} \mathrm{C}$, and temperate, wet winters with a mean minimum temperature of $9^{\circ} \mathrm{C}$. Here, the mean annual rainfall is between 530 and $740 \mathrm{~mm}$, with a heavy rain period from November to January [11], and then this area can be classified as semi-arid biancana badlands [49]. The rain follows the Mediterranean rainfall trend that showed a general reduction in the total annual precipitation, as well as an increase in the rainfall intensity in the last decades of the 20th century, followed by an increase in both the total precipitation and daily rainfall amounts since the beginning of the 21st century [50]. Furthermore, the previous increases in the lengths of the dry periods during winter and spring were followed by a decrease in the dry-spell lengths in all seasons in recent decades. In the study area, at the Aliano gauge station, an analysis of pluviometric data shows an annual mean precipitation of approximately $750 \mathrm{~mm}$, with precipitation mainly concentrated between October and January. An increase in rainfall intensity occurred between 1955 and 2000, despite a net decrease in the total annual precipitation, highlighted by the increase in consecutive dry days and the decrease in consecutive wet days recorded at Aliano [50]. 


\subsection{TLS Survey and Data Processing}

The lidar technology and the photogrammetry are non-contact survey methods avoiding unnecessary disturbance to highly erodible badland surfaces, obtaining 3D models of great accuracy and density [25]. The lidar technology is based on the principle of sending out a laser pulse and observing the time it takes for the pulse to reflect off an object and return to the instrument sensor. The distance range is combined with high-resolution angular encoder measurements to provide the three-dimensional location of the observed point [51]. A high-speed, high-accuracy Leica HDS 3000 terrestrial laser scanner was used [52], and the result obtained was a point cloud.

TLS surveys of the Aliano badlands were conducted in 2006, between the 30th and 31st of March, and on the 19th of May in 2016. In accordance with the topography of the study area, the TLS was strategically positioned in several locations to cover, as much as possible, the ground surface (Figure 2a). In fact, multiple scans at different locations were required to capture the entire survey site because the scanner line-of-flight was obscured by domes and brushes in one or more of the scan locations. We also chose these locations as a compromise between the survey cover needs and the battery life. The scan resolutions ranged between 30 and $50 \mathrm{~mm}$, both horizontally and vertically, to obtain the ground morphology. Each scan had to contain the highest-resolution control points (targets, Figure 2c) of the previous scan, thus providing overlap locations at which to join the scans into one single point cloud representing the whole site.

The data processing, conducted with Cyclone ${ }^{\odot}$ software [52], generated 3D point clouds composed of millions of points according to the previously arranged spatial resolution; the positions of the overlapping targets were surveyed by differential GPS to geo-reference the whole point cloud. We collected 5 scans in 2006 and 3 scans in 2016, and we merged the scans of each year using a registration process. The RMSEs in the scan registration were $0.002 \mathrm{~m}$ for the 2006 survey and $0.003 \mathrm{~m}$ for the 2016 survey.

Further data processing was performed using CloudCompare software version 2.10 [53]. The sparse vegetation on the ground surface was mostly removed by the filter tool (CANUPO) based on user-defined ground identifications [54], while multi-temporal change detection between the 2006 and 2016 point clouds was performed by the Multiscale Model to Model Cloud Comparison (M3C2) plugin [55]. This algorithm produces a new point cloud that shows the distance between the previous point clouds (CoD, cloud of difference) and allows the assessment of data accuracy by showing the level of detection (LOD) at 95\% and the significant changes using $3 \mathrm{D}$ models. The $\mathrm{LOD}_{95 \%}$ represents the spatially variable confidence intervals of distance measurements and comes from the given combination of different sources of uncertainties, such as the position uncertainty of the point clouds due to instrument precision, the registration errors between point clouds, and the surface roughness $[30,55]$. Hence, the measured distance was accurate where the change was greater than the estimated errors in $95 \%$ of the cases and where the statistically significant changes were visible on the point clouds, since the algorithm returned all these values stored in the attribute table of the point cloud.

A further step in point cloud processing was made using a geographic information system (GIS) to combine the biancane morphology with the multi-temporal changes and to detect the locations where erosion and accumulation take place. Interpolating the 2016 biancane point cloud produced a DEM of the study area; by operating on this DEM, the QGIS 3.2 tools allowed the slope angle and the exposure to be calculated. IDW interpolation was applied on the $\mathrm{CoD}$ derived with the $\mathrm{M} 3 \mathrm{C} 2$ plugin to create a raster of changes detected on the slope. Finally, this CoD raster was combined with the both slope $\left(<45^{\circ} ;>45^{\circ}\right)$ and exposure $\left(315^{\circ}<\mathrm{x}<45^{\circ} ; 45^{\circ}<\mathrm{x}<135^{\circ} ; 135^{\circ}<\mathrm{x}<225^{\circ} ; 225^{\circ}<\mathrm{x}<315^{\circ}\right)$ values. For the resulting six rasters, the main parameters of the descriptive statistics were computed by QGIS tools in order to compare them and understand how the positive and negative values are distributed on topography. Further analysis was performed in MATLAB ${ }^{\circledR}$ to combine the CoD raster and the exposure and slope values to highlight the distribution of erosion rates. 


\subsection{Rain and Wind Data}

We collected rain and wind data from the ALSIA (Agenzia Lucana di Sviluppo e di Innovazione in Agricoltura) station at Baderta Murgine (40.285929 $\mathrm{N}$ latitude, $16.316918^{\circ}$ E longitude) near Aliano, approximately $2.8 \mathrm{~km}$ south-eastward from the study area. These data cover the timespan between the first and last survey, and they were collected at both daily and hourly rates.

The data were filtered accordingly with daily and hourly combined conditions of rain and wind, and then displayed in rose diagrams.

We considered the wind direction of the events with daily rainfall amounts greater than $30 \mathrm{~mm}$, according to the method of Piccarreta et al. [14], to highlight on what sides and how many times rainfall events caused severe rill erosion and mass movements. Moreover, among these events, we selected those that occurred with a daily maximum wind speed greater than $6 \mathrm{~m} / \mathrm{s}$, as this is an important threshold value for raindrop diversion in WDR [36].

Similarly, we considered the wind direction during events with daily rainfall amounts greater than $10 \mathrm{~mm}$, the threshold for erosion occurrence according to Piccarreta et al. [14], and we also investigated when these events occurred coupled with a daily maximum wind speed greater than $6 \mathrm{~m} / \mathrm{s}$.

To support the contemporary occurrence of both intense rain and intense wind, we also analysed the hourly data. According to the rainfall intensity classification [56] (Table 1), rainfall rates between 2.5 and $10 \mathrm{~mm} / \mathrm{h}$ are considered moderate, while rainfall rates over $10 \mathrm{~mm} / \mathrm{h}$ are considered heavy. We took into account the wind directions during events with rainfall rates $>10 \mathrm{~mm} / \mathrm{h}$ and those with rainfall rates $>6 \mathrm{~mm} / \mathrm{h}$, since the latter is the rainfall intensity that causes significant erosion according to Foulds and Warburton [57]. We then combined the rain events with rainfall rates $>10 \mathrm{~mm} / \mathrm{h}$ and $>6 \mathrm{~mm} / \mathrm{h}$ with contemporaneous occurrences of hourly mean wind speeds greater than the threshold representing a gentle breeze on the Beaufort scale [35]. This value is $3.4 \mathrm{~m} / \mathrm{s}$ and also corresponds to the middle of the ascending stretch of the graph in Figure 3 in Schmidt et al. [36], showing raindrop diversion from the vertical direction as a function of wind speed. Since hourly mean wind speeds greater than $3.4 \mathrm{~m} / \mathrm{s}$ rarely occur, we also investigated rain events with rainfall rates $>10 \mathrm{~mm} / \mathrm{h}$ and $>6 \mathrm{~mm} / \mathrm{h}$ that occurred contemporaneously with maximum hourly wind speeds greater than $6 \mathrm{~m} / \mathrm{s}$, corresponding to a moderate breeze, that is, the wind speed over which the splash and sheet erosion process increases significantly [39].

Table 1. Rain intensity classifications according to the World Meteorological Organization, 2018.

\begin{tabular}{cc}
\hline Rain Range Intensity, $\mathbf{i}(\mathbf{m m} / \mathbf{h})$ & Classification \\
\hline$<2.5 \mathrm{~mm} / \mathrm{h}$ & Slight \\
\hline $2.5 \leq \mathrm{i}<10$ & Moderate \\
\hline $10 \leq \mathrm{i}<50$ & Heavy \\
\hline $\mathrm{i} \geq 50$ & Violent \\
\hline
\end{tabular}



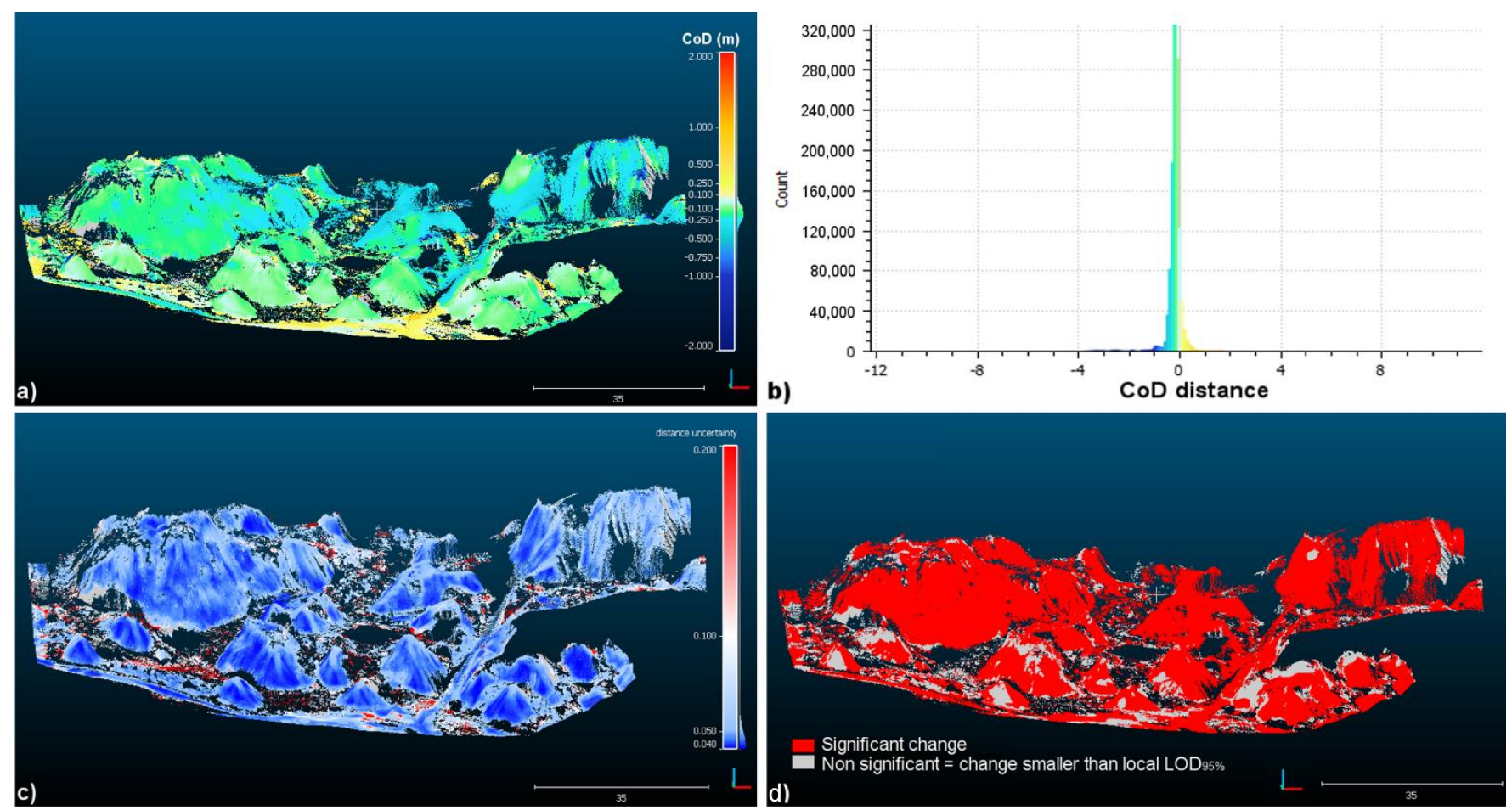

Figure 3. Topographical changes detected in the biancane point clouds; all numeric values are in metres; (a) south-side view of the $\mathrm{CoD}$; (b) histogram showing the distribution of the values in (a); (c) uncertainty values shown as level of change detection at $95 \%$; (d) statistically significant changes [55] derived from the combination of the CoD (a) and uncertainty (c).

\section{Results}

\subsection{Erosion Dynamics: TLS Survey and 3D Model}

Erosion and accumulation are represented by negative and positive values, respectively, since these amounts represent the distances between the points in the 2006 cloud and those in the 2016 cloud.

The resulting values are negative in almost the entire study area, indicating erosion, while positive values showing accumulation are present only in the areas between biancane in the lower part of the study area. The erosion values are larger on the tallest biancane located in the upper part of the study area, while the erosion values are lower on the smallest biancane located in the lower part of the study area (Figure 3a). However, the tallest biancane topped by shrubs shows lower erosion values on the upper parts of the slopes. The bulk of the values range between $-0.43 \mathrm{~m}$ and $-0.045 \mathrm{~m}$, with a mean of $-0.23 \mathrm{~m}$, resulting in a mean erosion rate of approximately $0.023 \mathrm{~m} / \mathrm{y}$ (Figure $3 \mathrm{~b}$ ). The bulk of positive values range from $0.04 \mathrm{~m}$ to $0.14 \mathrm{~m}$. with a mean of $0.09 \mathrm{~m}$, for an accumulation rate of $0.009 \mathrm{~m} / \mathrm{y}$. Figure $3 \mathrm{c}$ shows the spatial distribution of the measurement uncertainties. The uncertainty distribution is low almost everywhere and, as consequence, the changes detected are significant on almost all the hillslope (Figure 3d).

Most of the biancane sides are steeper than $45^{\circ}$, with the steepest slope values greater than $60^{\circ}$, and most biancane are south- and southeast-oriented (Figures 4 and 5). The processing of digital data allows us to measure how the CoD varies in the area, both for biancane sides with slope angles greater and lower than $45^{\circ}$ and according to the orientation of the sides (Figure 5). In the CoD raster with slope angles lower than $45^{\circ}$, there are more pixels with positive values, indicating accumulation, than in the raster with slope angles greater than $45^{\circ}$. Even though the majority of the area has a slope angle under $45^{\circ}$ (Figure $5 a, b$ ), most of the pixels with the highest negative values, indicating erosion, correspond to slopes greater than $45^{\circ}$. The CoD rasters containing the east- and south-facing sides (Figure $5 \mathrm{c}, \mathrm{d}$ ) show many more pixels with positive values than do the north- and west-facing CoD rasters (Figure 5e,f). However, the CoD raster containing 
north-oriented sides shows the highest negative pixel values, followed by the west-oriented CoD raster.
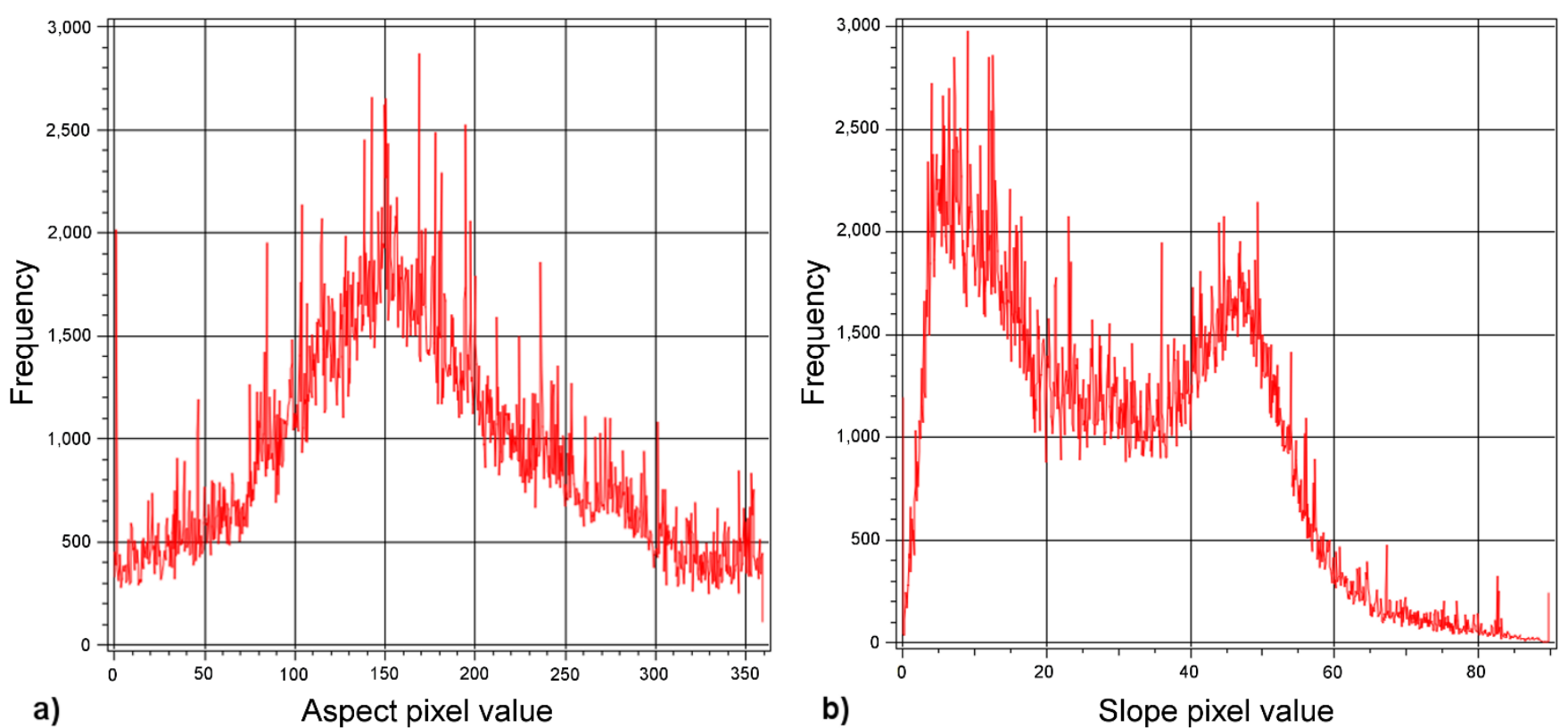

Figure 4. (a) Pixel value frequency of the aspect raster that shows the exposure of biancane relief; the highest frequency is between 90 and 220, that is, from E-SE to SW; (b) pixel value frequency of the slope raster; although most pixel values are lower than $40^{\circ}$, several pixels have values over $60^{\circ}$, and a secondary peak is visible around a value of $50^{\circ}$.

Statistical analyses aided in determining how the erosion changed on the hillslope sides. The statistical parameter distribution for each raster considered all the pixels that ranged from the maximum value of approximately $8 \mathrm{~m}$ to the minimum value of approximately $-6 \mathrm{~m}$. These extreme values occurred due to noise still present in the point clouds since it was very difficult to erase all the no-terrain points (e.g., vegetation). Table 2 reports the statistical parameters of the six rasters processed according to the slope and aspect distributions: differences are noticeable in the ranges of the most frequent pixel values and in the quantities of these pixels, as noticeable by the $\%$ of area.

The mean, median, mode, and standard deviation values of the pixel distributions in the $\mathrm{CoD}$ rasters on slopes over $45^{\circ}$ confirm that the most negative values, corresponding to higher erosion rates, are located on the steepest slopes.

The analysis of the pixel distribution of the $\mathrm{CoD}$ rasters selected according to the exposure shows that the highest mean and median values are those of the west-exposure raster, while the highest mode is that of the south-exposure raster. These results can be related to the large quantity of pixels in the south-exposure raster, many of which have positive values that lower both the mean and the median, although most of the pixels consist of the highest negative values of the whole study area.

The mean pixel values of the raster with slope angles greater than $45^{\circ}$ are the highest among all rasters, even though the raster of the west exposure has a quite similar mean. The great difference between these two rasters is in the mode value, which is higher for the slope raster and indicates that the negative values are higher in the slope raster than those in the west-exposure raster. Additionally, the mode value of the slope angle raster is greater than that of the south-exposure raster, showing that the slope is an important factor leading to erosion.

To highlight the correlations between erosion and exposure and between erosion and slope angle, a bivariate histogram was calculated with only the negative CoD values ranging between $-1 \mathrm{~m}$ and $0 \mathrm{~m}$ (Figure 6); the greatest negative outlier values were not taken into account since they probably occurred due to noise in the point clouds. Figure 6a 
shows that most of the pixels with low negative values are concentrated in the SW hillsides, while the pixels with slightly higher negative values are located in the $S$ and $W$ hillsides of biancane. Figure $6 \mathrm{~b}$ shows that most of the pixels with negative values are concentrated on the steepest slopes, with angles around $60^{\circ}$, and a second peak is observed around slope angles just beneath $20^{\circ}$.

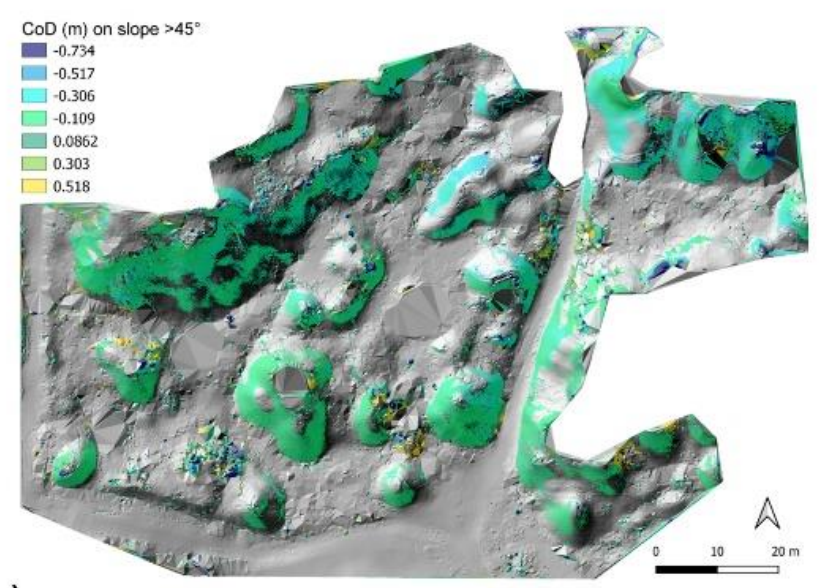

a)

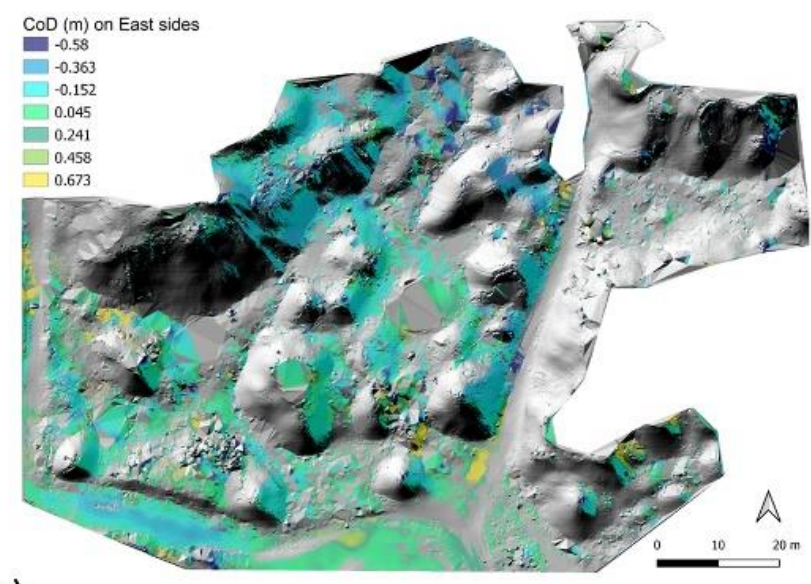

c)

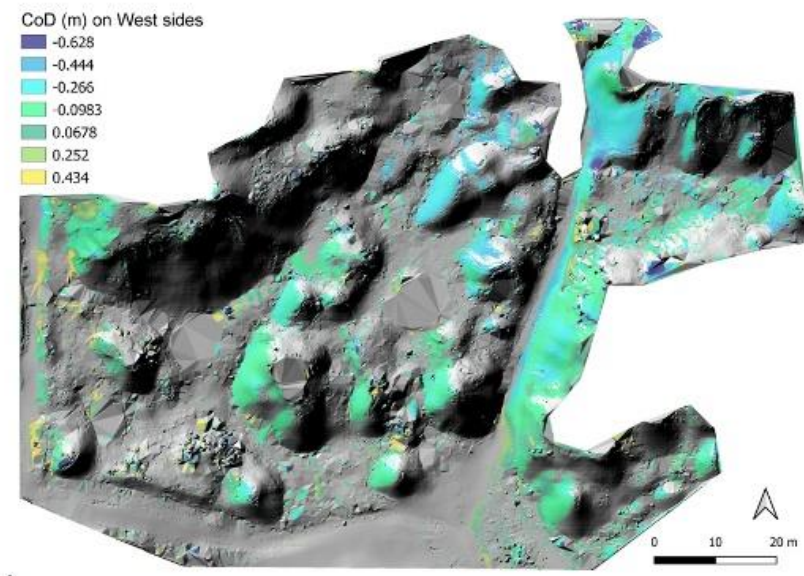

e)

Figure 5. The CoD rasters selected according to the side slope angles: (a) greater than $45^{\circ}$ and (b) lower than $45^{\circ}$; and the side exposures facing: (c) east, (d) south, (e) west, and (f) north. The CoD values are in metres.

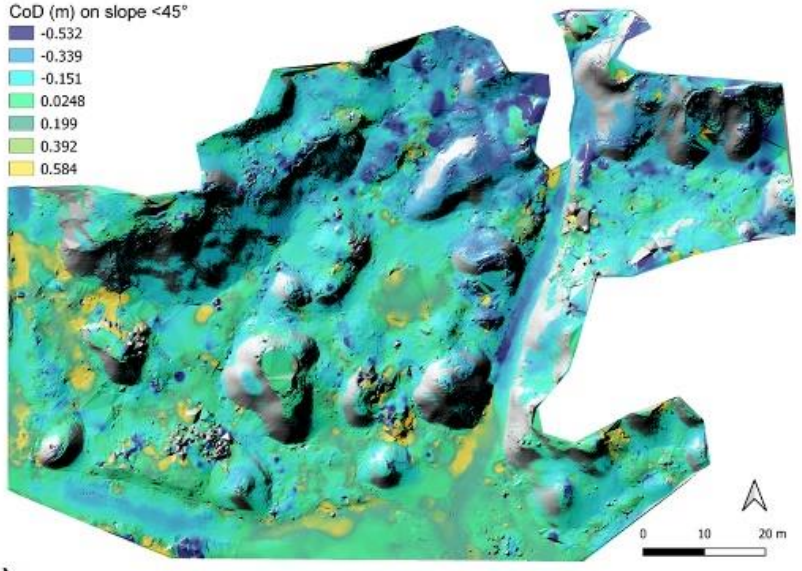

b)

d)
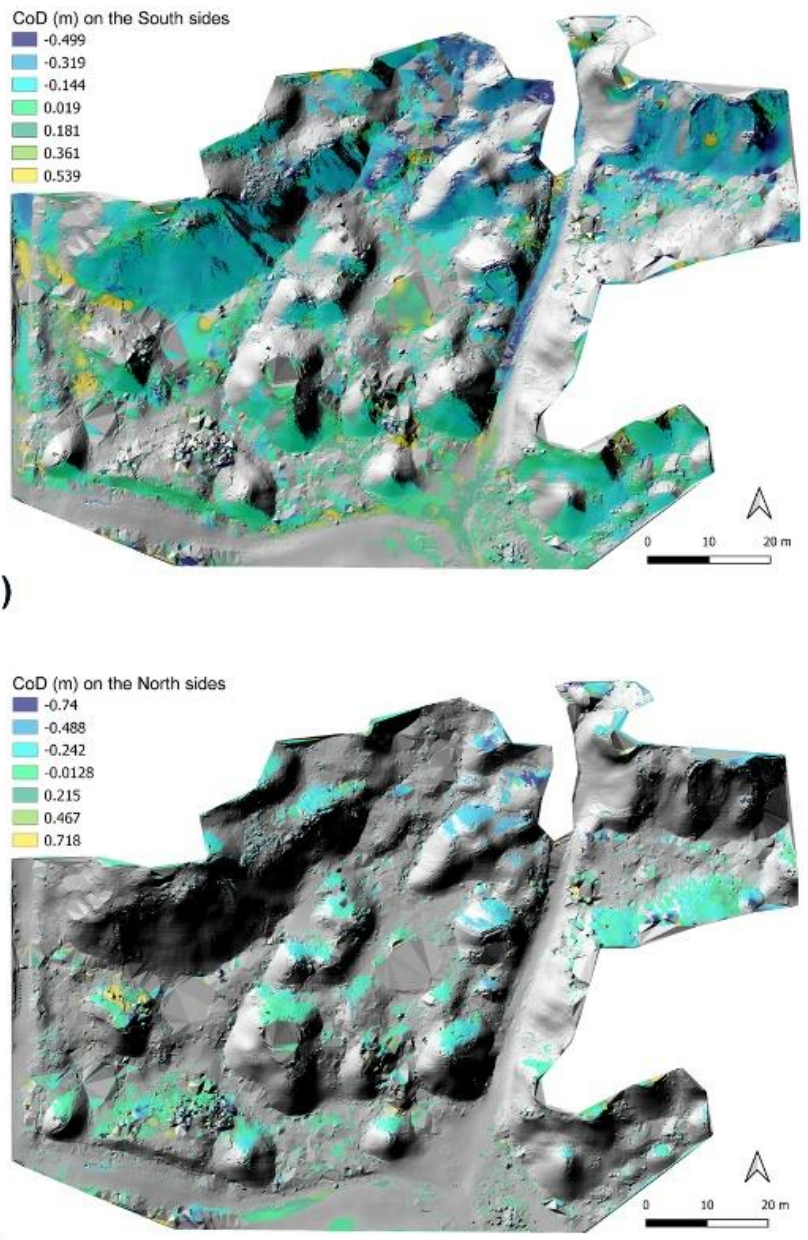

f) .

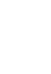


Table 2. Quantity (\%) of study area occupied by pixel values and the statistical parameters computed for the pixel distributions of the six rasters processed according to the slopes and exposures of biancane hillsides.

\begin{tabular}{cccccc}
\hline & \% of Area & Mean Value & $\begin{array}{c}\text { Standard } \\
\text { Deviation }\end{array}$ & Median & Mode (Distribution Peak) \\
\hline Slope over $45^{\circ}$ & 23.52 & -0.13567 & 0.40428 & -0.14830 & -0.16416 \\
\hline Slope under $45^{\circ}$ & 76.37 & -0.07019 & 0.34575 & -0.10719 & -0.1224 \\
\hline North sides $\left(315^{\circ}<\mathrm{x}<45^{\circ}\right)$ & 11.92 & -0.10162 & 0.42931 & -0.12574 & -0.1375 \\
\hline East sides $\left(45^{\circ}<\mathrm{x}<135^{\circ}\right)$ & 28.1 & -0.05777 & 0.35807 & -0.09873 & -0.102 \\
\hline South sides $\left(135^{\circ}<\mathrm{x}<225^{\circ}\right)$ & 39.8 & -0.07755 & 0.35020 & -0.12055 & -0.1586 \\
\hline West sides $\left(225^{\circ}<\mathrm{x}<315^{\circ}\right)$ & 19.79 & -0.13247 & 0.33589 & -0.14227 & -0.11915 \\
\hline
\end{tabular}
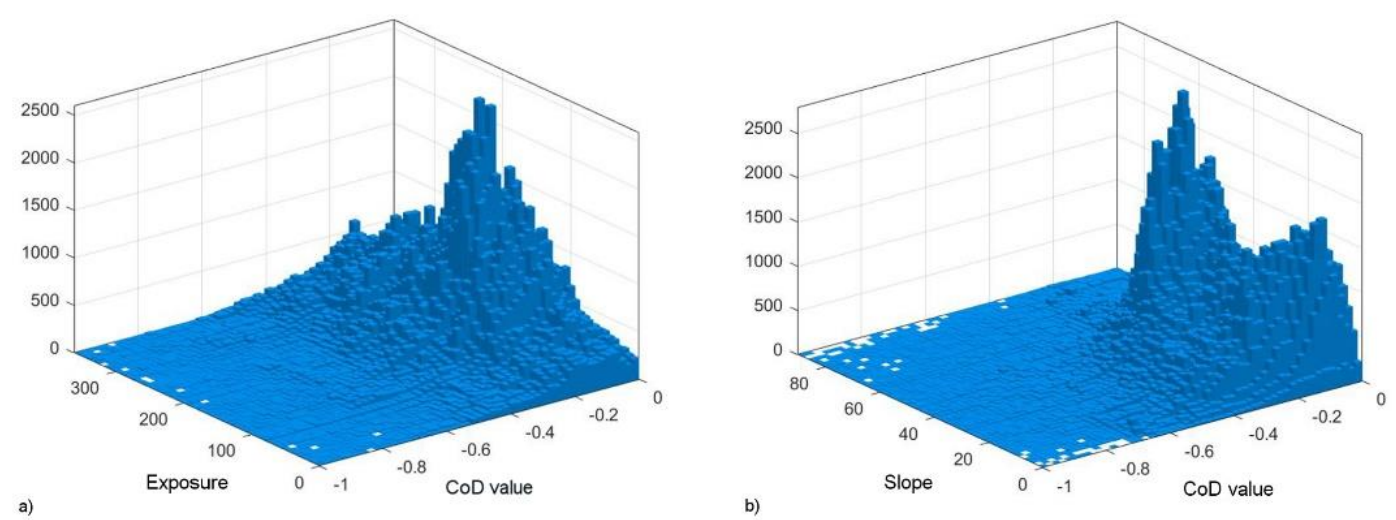

Figure 6. Bivariate histograms calculated by comparing the CoD values with (a) the exposures and (b) the slope angles; the CoD values ranged between -1 and 0 metres.

\subsection{Rain Intensity and WDR Condition}

Rain and wind data collected at the Baderta Murgine gauge station were filtered to highlight the wind directions during different events. The climatic data collected in the time lapse between the first and last TLS surveys show approximately 200 days with daily rainfall amounts greater than $10 \mathrm{~mm}$ (Figure 7a), and only approximately 30 days with daily rainfall amounts over $30 \mathrm{~mm}$ (Figure 7c). Figure 7a shows the wind directions during events with daily rainfall amounts greater than $10 \mathrm{~mm}$; heavy rainfall occurred contemporarily with wind from all the main cardinal points. Events with a daily rainfall amount greater than $30 \mathrm{~mm}$ mainly occurred with the ESE wind direction and with wind coming from the NW and SW directions (Figure 7c).

Filtering the events of daily rainfall amounts greater than $10 \mathrm{~mm}$ and the daily maximum wind speeds greater than $6 \mathrm{~m} / \mathrm{s}$, we observe that there is a prevalent SW and NW wind direction, but wind coming from the eastern side is also important (Figure 7b).

For the events of daily rainfall amounts greater than $30 \mathrm{~mm}$ with a daily maximum wind speed greater than $6 \mathrm{~m} / \mathrm{s}$, we observe that there is a strong prevalence of the SW and NW wind directions (Figure $7 \mathrm{~d}$ ).

The above analyses do not endorse the contemporary occurrence of both intense rain and fast wind, which we investigated considering the hourly data. The number of events with rainfall rates $>6 \mathrm{~mm} / \mathrm{h}$ (moderate rain) was 159 , and most of these events continued for more than one hour, with wind that mainly came from the NW, W, SW, S, and SE directions (Figure 8a). The number of events with recorded rainfall rates $>10 \mathrm{~mm} / \mathrm{h}$ (heavy rain) was 56; only in a few cases did heavy rainfall continue for two hours, and these events were contemporary with winds coming from the NE, S, and W directions (Figure 8d). We combined rainfall rates greater than $6 \mathrm{~mm} / \mathrm{h}$ (Figure $8 \mathrm{~b}, \mathrm{c}$ ) and greater than $10 \mathrm{~mm} / \mathrm{h}$ (Figure $8 \mathrm{e}, \mathrm{f}$ ) with both hourly maximum wind speeds greater than $6 \mathrm{~m} / \mathrm{s}$ and hourly mean 
wind speeds greater than $3.4 \mathrm{~m} / \mathrm{s}$. For rainfall rates greater than $6 \mathrm{~mm} / \mathrm{h}$, we found that the predominant wind directions were the $\mathrm{NW}, \mathrm{W}$, and $\mathrm{SW}$ directions for maximum hourly wind speeds greater than $6 \mathrm{~m} / \mathrm{s}$ (Figure $8 \mathrm{~b}$ ), and the $\mathrm{S}, \mathrm{W}$, and NE directions for hourly mean wind speeds greater than $3.4 \mathrm{~m} / \mathrm{s}$ (Figure $8 \mathrm{c}$ ). The number of hours for which the first type of event was recorded was 133, while the number of hours for which the last type of event was recorded was only 21.

\begin{tabular}{l|l|c|c|c|c|}
\hline \multirow{2}{*}{ Rain } & \multicolumn{3}{c}{ Wind direction } \\
\hline$>10 \mathrm{~mm} / \mathrm{d}$ & no wind speed limit & $\begin{array}{l}\text { daily maximum wind } \\
\text { speed greater than } 6 \mathrm{~m} / \mathrm{s}\end{array}$ \\
\hline $30 \mathrm{~mm} / \mathrm{d}$ & &
\end{tabular}

Figure 7. Wind directions during events with: (a) rainfall rates greater than $10 \mathrm{~mm} / \mathrm{d}$; (b) rainfall rates greater than $10 \mathrm{~mm} / \mathrm{d}$ and daily maximum wind speeds greater than $6 \mathrm{~m} / \mathrm{s}$; (c) rainfall rates greater than $30 \mathrm{~mm} / \mathrm{d}$; and (d) rainfall rates greater than $30 \mathrm{~mm} / \mathrm{d}$ and daily maximum wind speeds greater than $6 \mathrm{~m} / \mathrm{s}$. The number of days is shown in red.

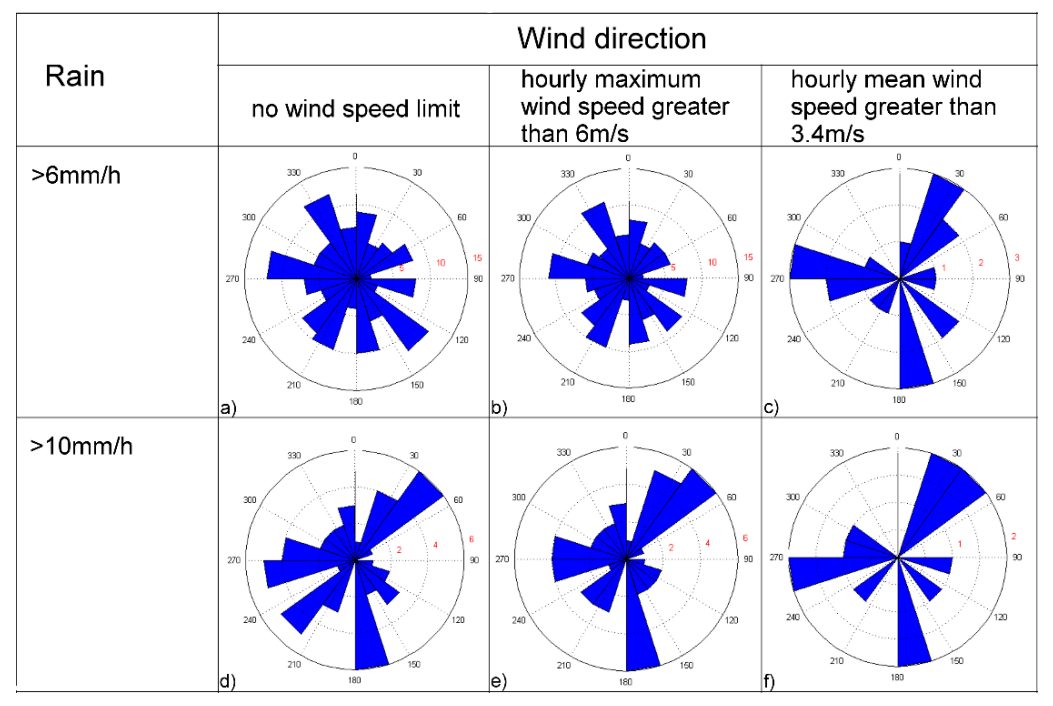

Figure 8. (a) Wind directions during hourly rainfall events greater than $6 \mathrm{~mm}$; (b) wind directions during rainfall rates greater than $6 \mathrm{~mm} / \mathrm{h}$ and hourly maximum wind speeds greater than $6 \mathrm{~m} / \mathrm{s}$; (c) wind directions during rainfall rates greater than $6 \mathrm{~mm} / \mathrm{h}$ and hourly mean wind speeds greater than $3.4 \mathrm{~m} / \mathrm{s}$; (d) wind directions during hourly rainfall rates greater than $10 \mathrm{~mm}$; (e) wind directions during rainfall rates greater than $10 \mathrm{~mm} / \mathrm{h}$ and hourly maximum wind speeds greater than $6 \mathrm{~m} / \mathrm{s}$; and (f) wind directions during rainfall rates greater than $10 \mathrm{~mm} / \mathrm{h}$ and hourly mean wind speeds greater than $3.4 \mathrm{~m} / \mathrm{s}$. The number of hours is shown in red. 
For rainfall rates greater than $10 \mathrm{~mm} / \mathrm{h}, 50$ events were recorded, and the predominant wind directions during these events were the NE, S, and $\mathrm{W}$ directions for hourly maximum wind speeds greater than $6 \mathrm{~m} / \mathrm{s}$ (Figure 8e), while, during 13 events, the same directions were also prevalent for hourly mean wind speeds greater than $3.4 \mathrm{~m} / \mathrm{s}$ (Figure $8 \mathrm{f}$ ).

Analysing the events, most of the time, rainfall amounts $>6 \mathrm{~mm}$ are characterised by associated moderate to strong breezes (Beaufort scale [35]), while events with more intense winds are less frequent (Figure 9a), and their quantities decrease with increasing wind speeds. Hourly rainfall amounts $>10 \mathrm{~mm}$ are frequently combined with strong breezes, followed by winds from moderate to fresh breezes, and many events are linked to near-gales or gales (Figure $9 b$ ).

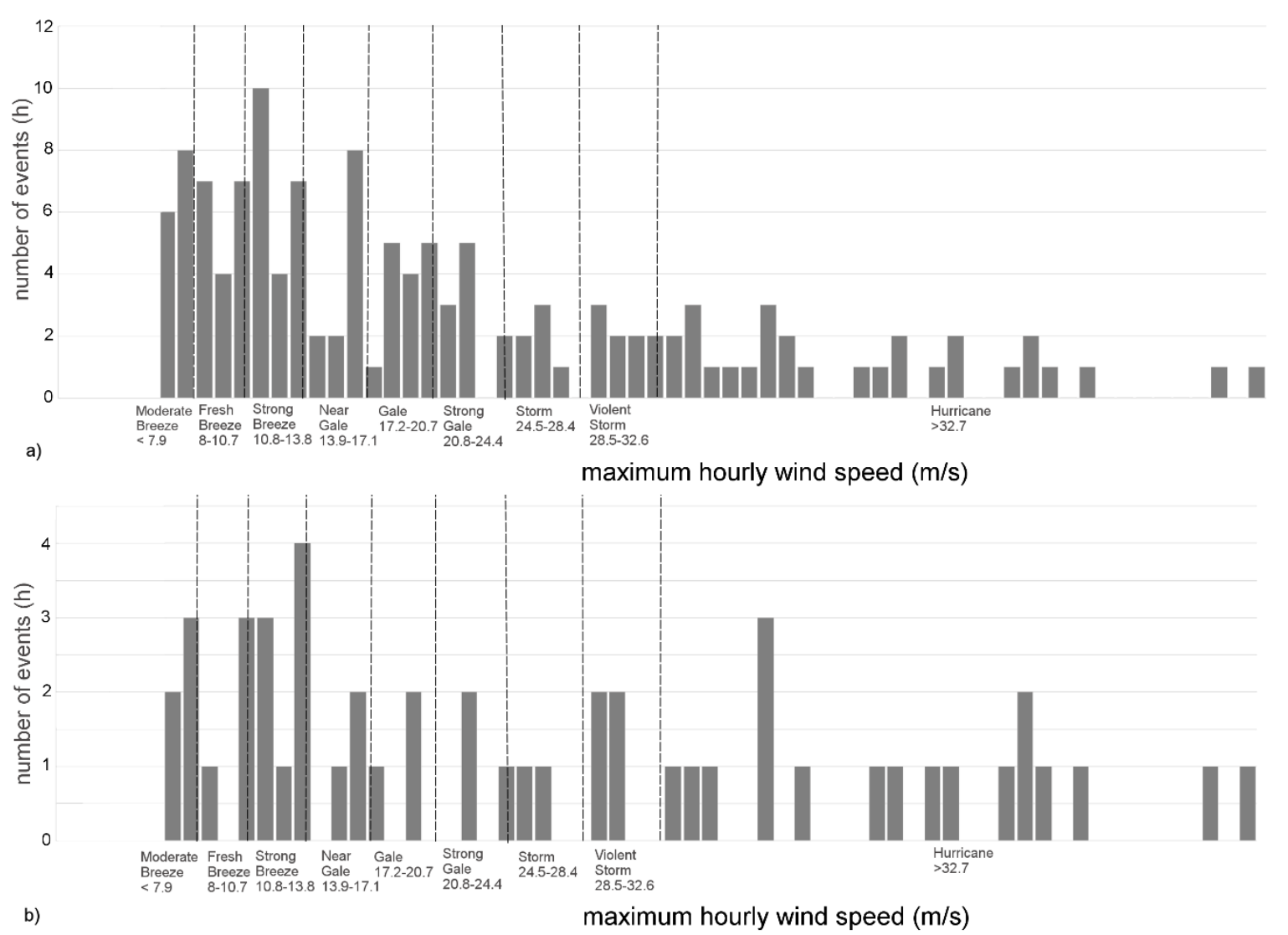

Figure 9. (a) Frequencies of the different wind speed classes for all events with hourly rainfall amounts greater than 6 $\mathrm{mm}$; the most frequent events are linked to wind speeds $>6 \mathrm{~m} / \mathrm{s}$ and $<17 \mathrm{~m} / \mathrm{s}$ corresponding to moderate $(<7.9 \mathrm{~m} / \mathrm{s})$, fresh $(8-10.7 \mathrm{~m} / \mathrm{s})$ and strong $(10.8-13.8 \mathrm{~m} / \mathrm{s})$ breezes, and near-gales $(13.9-17.1 \mathrm{~m} / \mathrm{s})$; (b) frequencies of the different wind speed classes during all events with hourly rainfall amounts greater than $10 \mathrm{~mm}$; some events occurred with strong breezes $(10.8-13.8 \mathrm{~m} / \mathrm{s})$, then with moderate breeze $(<7.9 \mathrm{~m} / \mathrm{s})$, and several occurred with winds classified as hurricane speeds.

\section{Discussion}

Our analysis led to the assessment of the local rate of erosion and deposition over an approximately 10-year timespan with high resolution data. Detailed survey is nowadays possible thanks to the large use of both the LiDAR and SfM technologies and tools that favour and improve the point clouds processing. This study confirms that the TLS survey is the most suitable technology for the hillslope scale monitoring, since it is a good technology between the survey time and spatial resolution. Moreover, the use of open-source software and their plugins greatly improves all the monitoring process.

Previous studies focused on detailed topographic changes on calanchi and on greater catchment slopes [25-30] rather than on biancana badlands. These works were carried out over a shorter timespan by frequent surveys, usually after intense rainfall events. The 
comparison of only two multi-temporal point clouds over a 10-year timespan is quite long and is not a common timespan record to be surveyed by TLS. Nevertheless, thanks to a continuous dataset of weather conditions recorded in the same time span, this approach allowed us to appreciate how topographic changes occur on the biancane hillslope in relation to the occurrence of all effective combinations of wind direction and rain intensity. Our results show that the mean rate of erosion is approximately $0.023 \mathrm{~m} / \mathrm{y}$, which is in accordance with the rates found in previous works (e.g., [10] and references therein), and the mean rate of deposition is about $0.009 \mathrm{~m} / \mathrm{y}$, but topographic changes are not evenly distributed on the hillslope and on dome sides. The sediment movement and its budget in the biancane landscape is a consequence of the tectonic-lithological and climatic setting $[4,8,40,58-61]$, and changes in the erosion and deposition rates drive the geomorphological evolution of the biancane reliefs.

On the other hand, the relief and exposure of the land surface can influence the erosion and deposition rates in the biancana badlands. Over approximately 10 years, the study area suffered a more intense erosion than deposition, as shown by the descriptive statistical analysis on the CoD value. These topographical changes were not spatially uniform on the biancane hillsides, since high slope angle and exposure played an important role in the erosion of the slopes. A significant relationship between aspect and topographic change was demonstrated by several authors $[9,13,20,27]$. In semi-arid badlands, the south facing slopes show poor or no vegetation cover due to control of soil water availability, while the north-facing slopes show higher vegetation cover $[4,62-64]$. In the study area, although erosion was widespread on almost all domes, the analysis of the CoD raster showed that all the southern (with the highest mode, Table 2) and western (with the highest median and mean value, Table 2) sides of biancane suffer the most intense erosion, and sediments come from steep bare south- and west-oriented slopes into lower topographic areas between domes. Moreover, our analysis highlighted that erosion does not act evenly on the whole hillside, but is more intense in the upper part of the surveyed area where the slopes were greater than $45^{\circ}$. Combining these factors, we can assess that the steepest southwestern part of the hillsides suffered the highest erosion. These results could be due to both the greater insolation acting on the clay cohesion (exposure effect) and to the sediment movement that acts on the slope under the control of gravity (slope angle effect). Although previous study fixed the role of topography in the badlands slope gradient maintenance $[9,13,17,25]$, the CoD shows in detail how the sediments moved on hillslopes. The detailed survey and the long timespan are also useful in order to suppose the way the runoff took place under different rainfall conditions. In fact, our results confirm what was previously stated under rainfall simulation [34]: sediment concentration in runoff is positively influenced by slope angle, as sediment displacement is caused by splash and sheet erosion due to the rainfall $[37-39,63,65]$ that hits the sides of biancane. Our study shows that the necessary conditions for intense rill erosion and mass movements on slopes (rain $>30 \mathrm{~mm} / \mathrm{d}$, [14]) rarely occur (approximately 30 days in 10 years) in the study area, but the conditions that cause erosion (rain $>10 \mathrm{~mm} / \mathrm{d},[14]$ ) are more frequent, occurring approximately 200 days in the 10-year study period in these semi-arid badlands, where the mean annual rainfall is between 530 and $740 \mathrm{~mm}$ [10]. As a consequence, the rainfall intensity over $10 \mathrm{~mm} / \mathrm{d}$ is critical in generating runoff in the area but, as several studies have shown [36-38,66,67], wind is also an important factor in controlling runoff and soil erosion, since it contributes to increasing rainfall action. Despite the important role of WDR, all previous studies were performed in controlled environments (e.g., artificial rain and wind in wind tunnel) and no relation was stated with erosion rate on biancana badlands. By combining the daily rain with wind speed, our analysis highlights that the unstable weather linked to intense wind comes from all $\mathrm{E}$ quadrants, from $\mathrm{S}$ and $\mathrm{W}$. The more intense events are mostly linked to western winds; they rarely occurred in the surveyed timespan, but their action on slopes contributed anyway to the changes detected in this study on the exposed sides.

The daily values did not guarantee the simultaneous occurrence of wind and rainfall; hence, we combine the rain and wind speed records of the same hours greater than the 
thresholds indicated in Section 2.3 in order to find the WDR. The rainfall with moderate to strong breeze mostly affected dome sides facing $\mathrm{W}$ and $\mathrm{S}$ directions; when rainfall intensity and wind speed increase, the most affected sides were those facing NE, S, and W. Finally, we observed that rainfall $>6 \mathrm{~mm} / \mathrm{h}$ was relatively frequent and was associated with winds of moderate force coming from the western and southern sides. As the wind speed increased, more intense events generally came from the NE direction and from the western directions, and, despite their low frequency, the actions of these events could cause erosion on slopes in any case, as shown by the CoD. In the study area, stronger events rarely occurred, and the contribution to slope erosion was mainly due to the more frequent winds of moderate forces, combined with moderate-to-heavy rainfall events. Since this WDR generally comes from the southern directions (mainly SW and S), it is also combined with the insolation (due to exposure) and gravity (due to slope angle) effects and contributes to an increase in soil erosion on the south and southwestern facing hillslopes. However, we detected that, in the case of more intense events, they acted also on slopes facing NE since WDR mainly comes from this direction and potentially contributes to erosion on these biancane sides, although insolation is less effective and particle cohesion is higher on these sides than those on the other sides. The relation between the main WDR directions and the orientation and slope of biancana hillslopes in the study area confirms how the local geomorphological setting strictly affects the runoff distribution.

Even if our work was not focused on this topic, the role of scrubs and bushes on top of some biancane is not negligeable in relation to both insolation and moderate or intense WDR. We know that the roots retain sediments [1,2], but the bush foliage also acts as an umbrella by shielding the upper part of slopes from both sun and WDR, partially reducing erosion. In fact, on the domes that had bushes on top, we could observe a reduction in erosion just beneath the shrubs, and this effect contributed to the steepness of the biancane slopes (Figure 3a).

\section{Conclusions}

The multi-temporal high-resolution topographical survey of biancane-dominated hillsides conducted in this study measured the medium-term rates of erosion and deposition over a 10-year timespan in this kind of landscape, and provided a detailed indication of how the erosion and deposition rates were spatially distributed. A comparison of two point clouds conducted by detecting the distances between homologous points led to a survey of how erosion and sediment accumulation act on domes and in the areas between them, allowing the assessment of the spatial distribution on erosion and deposition in a complex topographic setting. We related different rates of sediment loss to different side exposures and slope angles, obtaining the great influences of insolation, rainfall, and wind on erosion and sediment movement. In fact, the sides that suffered the greatest erosion were the southern and southwestern sides, clearly showing the relevance of insolation, cracking, and scarce vegetation to sediment loss. Rain is an important factor in sediment displacement, and its effect was directly dependent on the rainfall intensity and wind direction. Our results confirmed the role of WDR in sediment erosion since raindrops and soil particles are affected by the wind shear velocity. The most frequent WDR direction corresponded to the exposure direction that suffered the greatest erosion. We found that the most frequent moderate and heavy rains combined with moderate and heavy breezes came from the $\mathrm{S}$ and SW directions, where the erosion was higher. We found that more intense events acted on slopes facing NE, since WDR mainly came from this direction and potentially contributed to erosion on these biancane sides, although insolation was less effective and particle cohesion was higher than those on the other sides. The role of the bushes on top of the domes slightly mitigated the effects of WDR. 
Author Contributions: Conceptualization, A.M.; methodology, A.M.; software, A.M.; validation, A.M., V.D.S. and D.C.; formal analysis, A.M.; investigation, A.M. and D.C.; resources, D.C.; data curation, A.M. and V.D.S.; writing-original draft preparation, A.M.; writing-review and editing, V.D.S. and D.C.; visualization, A.M.; supervision, D.C.; project administration, D.C.; funding acquisition, D.C. All authors have read and agreed to the published version of the manuscript.

Funding: This research was funded by Program 2011-2013 PRIN (Response of morphoclimatic system dynamics to global changes and related geomorphologic hazard; National co-ordinator: C. Baroni; local Research Unit co-ordinators: G. Mastronuzzi).

Acknowledgments: We would like to thank the ALSIA (Agenzia Lucana di Sviluppo e di Innovazione in Agricoltura) for the rain and wind data from Baderta Murgine station, and M. Zingaro for MATLAB processing. We should like to thank the anonymous reviewers for their comments and suggestions that improved the content of the manuscript.

Conflicts of Interest: The authors declare no conflict of interest.

\section{References}

1. Torri, D.; Santi, E.; Marignani, M.; Rossi, M.; Borselli, L.; Maccherini, S. The recurring cycles of biancana badlands: Erosion, vegetation and human impact. Catena 2013, 106, 22-30. [CrossRef]

2. Bierbaß, P.; Wündsch, M.; Michalzik, B. The impact of vegetation on the stability of dispersive material forming biancane badlands in Val d'Orcia, Tuscany, Central Italy. Catena 2014, 113, 260-266. [CrossRef]

3. Bryan, R.B.; Yair, A. Perspectives of studies of badland geomorphology. In Badland Geomorphology and Piping; Bryan, R., Yair, A., Eds.; Geo Books: Norwich, UK, 1982; pp. 1-12.

4. Calvo-Cases, A.; Harvey, A.M. Morphology and development of selected badlands in southeast Spain: Implications of climatic change. Earth Surf. Process. Landf. 1996, 21, 725-735. [CrossRef]

5. Kuhn, N.; Yair, A. Spatial distribution of surface conditions and runoff generation in small arid watersheds, Zin Valley Badlands, Israel. Geomorphology 2004, 57, 183-200. [CrossRef]

6. Cocco, S.; Brecciaroli, G.; Agnelli, A.; Weindorf, D.; Corti, G. Soil genesis and evolution on calanchi (badland-like landform) of central Italy. Geomorphology 2015, 248, 33-46. [CrossRef]

7. Calzolari, C.; Ungaro, F. Geomorphic features of a badland (biancane) area (Central Italy) characterization, distribution and quantitative spatial analysis. Catena 1998, 31, 237-256. [CrossRef]

8. Vergari, F.; Della Seta, M.; Del Monte, M.; Fredi, P.; Lupia Palmieri, E. Long- and short-term evolution of several Mediterranean denudation hot spots: The role of rainfall variations and human impact. Geomorphology 2013, 183, 14-27. [CrossRef]

9. Pulice, I.; Di Leo, P.; Robustelli, G.; Scarciglia, F.; Cavalcante, F.; Belviso, C. Control of climate and local topography on dynamic evolution of badland from southern Italy (Calabria). Catena 2013, 109, 83-95. [CrossRef]

10. Brandolini, P.; Pepe, G.; Capolongo, D.; Cappadonia, C.; Cevasco, A.; Conoscenti, C.; Marsico, A.; Vergari, F.; Del Monte, M. Hillslope degradation in representative Italian areas: Just soil erosion risk or opportunity of development? Land Degrad. Dev. 2018, 29, 3050-3068. [CrossRef]

11. Alexander, D. Difference between "Calanchi" and "biancane" badlands in Italy. In Badland Geomorphology and Piping; Bryan, R., Yair, A., Eds.; Geo Books: Norwich, UK, 1982; pp. 71-88.

12. Torri, D.; Bryan, R.B. Micropiping processes and biancana evolution in southeast Tuscany, Italy. Geomorphology 1997, 20, 219-235. [CrossRef]

13. Farifteh, J.; Soeters, R. Origin of calanchi and biancane in East Aliano, southern Italy. Geomorphology 2006, 77, 142-152. [CrossRef]

14. Piccarreta, M.; Faulkner, H.; Bentivenga, M.; Capolongo, D. The influence of physico-chemical material properties on erosion processes in the badlands of Basilicata, Southern Italy. Geomorphology 2006, 81, 235-251. [CrossRef]

15. Bentivenga, M.; Agosta, F.; Palladino, G.; Piccarreta, M.; Prosser, G. Structural control on badland slope evolution: A case study from the southern Apennines (Italy). Geomorphology 2021, 374, 107518. [CrossRef]

16. Torri, D.; Colica, A.; Rockwell, D. Preliminary study of the erosion mechanisms in a Biancana badland (Tuscany, Italy). Catena 1994, 23, 281-294. [CrossRef]

17. Cantón, Y.; Solé-Benet, A.; De Vente, J.; Boix-Fayos, C.; Calvo-Cases, A.; Asensio, C.; Puigdefábregas, J. A review of runoff generation and soil erosion across scales in semiarid south-eastern Spain. J. Arid. Environ. 2011, 75, 1254-1261. [CrossRef]

18. Zingaro, M.; Refice, A.; Giachetta, E.; D’Addabbo, A.; Lovergine, F.; De Pasquale, V.; Pepe, G.; Brandolini, P.; Cevasco, A.; Capolongo, D. Sediment mobility and connectivity in a catchment: A new mapping approach. Sci. Total. Environ. 2019, 672, 763-775. [CrossRef]

19. Zingaro, M.; Refice, A.; D'Addabbo, A.; Hostache, R.; Chini, M.; Capolongo, D. Experimental Application of Sediment Flow Connectivity Index (SCI) in Flood Monitoring. Water 2020, 12, 1857. [CrossRef]

20. Ciccacci, S.; Galiano, M.; Roma, M.A.; Salvatore, M.C. Morphological analysis and erosion rate evaluation in badlands of Radicofani area (Southern Tuscany-Italy). Catena 2008, 74, 87-97. [CrossRef] 
21. Vandekerckhove, L.; Poesen, J.; Oostwoud Wijdenes, D.; Gyssels, G. Short-term bank gully retreat rates in Mediterranean environments. Catena 2001, 44, 133-161. [CrossRef]

22. Della Seta, M.; Del Monte, M.; Fredi, P.; Lupia Palmieri, E. Space-time variability of denudation rates at the catchment and hillslope scales on the Tyrrhenian side of Central Italy. Geomorphology 2009, 107, 161-177. [CrossRef]

23. Turowski, J.M.; Cook, K.L. Field techniques for measuring bedrock erosion and denudation. Earth Surf. Process. Landf. 2017, 42, 109-127. [CrossRef]

24. Aucelli, P.P.C.; Conforti, M.; Della Seta, M.; Del Monte, M.; D’Uva, L.; Rosskopf, C.M.; Vergari, F. Multi-temporal digital photogrammetric analysis for quantitative assessment of soil erosion rates in the Landola catchment of the upper Orcia valley (Tuscany, Italy). Land Degrad. Develop. 2016, 27, 1075-1092. [CrossRef]

25. Vericat, D.; Smith, M.W.; Brasington, J. Patterns of topographic change in sub-humid badlands determined by high resolution multi-temporal topographic surveys. Catena 2014, 120, 164-176. [CrossRef]

26. Smith, M.W.; Vericat, D. From experimental plots to experimental landscapes: Topography, erosion and deposition in sub-humid badlands from Structure-from-Motion photogrammetry Measuring erosion in dynamic landscapes. Earth Surf. Process. Landf. 2015, 40, 1656-1671. [CrossRef]

27. Neugirg, F.; Starka, M.; Kaiser, A.; Vlacilova, M.; Della Seta, M.; Vergari, F.; Schmidt, J.; Becht, M.; Haas, F. Erosion processes in calanchi in the Upper Orcia Valley, Southern Tuscany, Italy based on multitemporal high-resolution terrestrial LiDAR and UAV surveys. Geomorphology 2016, 269, 8-22. [CrossRef]

28. Llena, M.; Vericat, D.; Smith, M.W.; Wheaton, J.M. Geomorphic process signatures reshaping sub-humid Mediterranean badlands: 1. Methodological development based on high-resolution topography. Earth Surf. Process. Landf. 2020, 45, 1335-1346. [CrossRef]

29. Llena, M.; Smith, M.W.; Wheaton, J.M.; Vericat, D. Geomorphic process signatures reshaping sub-humid Mediterranean badlands: 2. Application to 5-year dataset. Earth Surf. Process. Landf. 2020, 45, 1292-1310. [CrossRef]

30. James, M.R.; Robson, S.; Smith, M.W. 3-D uncertainty-based topographic change detection with structure-from-motion photogrammetry: Precision maps for ground control and directly georeferenced surveys. Earth Surf. Process. Landf. 2017, 42, 1769-1788. [CrossRef]

31. Lu, X.; Li, Y.; Washington-Allen, R.A.; Li, Y.; Li, H.; Hu, Q. The effect of grid size on the quantification of erosion, deposition, and rill network. Int. Soil Water Conserv. Res. 2017, 5, 241-251. [CrossRef]

32. Vergari, F.; Troiani, F.; Faulkner, H.; Del Monte, M.; Della Seta, M.; Ciccacci, S.; Fredi, P. The use of the slope-area function to analyse process domains in complex badland landscapes. Earth Surf. Process. Landf. 2019, 44, 273-286. [CrossRef]

33. Anderson, R.S.; Anderson, S.P. Geomorphology: The Mechanics and Chemistry of Landscapes; Cambridge University Press: Cambridge, UK, 2010; p. 637.

34. Martínez-Murillo, J.F.; Nadal-Romero, E.; Regüés, D.; Cerdà, A.; Poesen, J. Soil erosion and hydrology of the western Mediterranean badlands throughout rainfall simulation experiments: A review. Catena 2013, 106, 101-112. [CrossRef]

35. Royal Meteorological Society. Beaufort Scale. 2018. Available online: https://www.rmets.org/resource/beaufort-scale (accessed on 15 December 2020).

36. Schmidt, J.; Werner, M.; Schindewolf, M. Wind effects on soil erosion by water-A sensitivity analysis using model simulations on catchment scale. Catena 2017, 148, 168-175. [CrossRef]

37. Erpul, G.; Gabriels, D.; Norton, L.D.; Flanagan, D.C.; Huang, C.H.; Visser, S. Raindrop and flow interactions for interrill erosion with wind-driven rain. J. Hydraul. Res. 2013, 51, 548-557. [CrossRef]

38. Marzen, M.; Iserloh, T.; de Lima, J.L.M.P.; Fister, W.; Ries, B.J. Impact of severe rain storms on soil erosion: Experimental evaluation of wind-driven rain and its implications for natural hazard management. Sci. Total Environ. 2017, 590-591, 502-513. [CrossRef] [PubMed]

39. Arshad, R.R.; Mahmoodabadi, M.; Farpoor, M.H.; Fekri, M. Experimental investigation of rain-induced splash and wash processes under wind-driven rain. Geoderma 2019, 337, 1164-1174. [CrossRef]

40. Peña-Angulo, D.; Nadal-Romero, E.; González-Hidalgo, J.C.; Albaladejo, J.; Andreu, V.; Bagarello, V.; Barhi, H.; Batalla, R.J.; Bernal, S.; Bienes, R.; et al. Spatial variability of the relationships of runoff and sediment yield with weather types throughout the Mediterranean basin. J. Hydrol. 2019, 571, 390-405. [CrossRef]

41. Clarke, M.L.; Rendell, H.M. The impact of the farming practice of remodeling hillslope topography on badland morphology and soil erosion processes. Catena 2000, 40, 229-250. [CrossRef]

42. Lentini, F.; Carbone, S.; Di Stefano, A. Note illustrative della Carta Geologica d'Italia alla scala 1:50.000-506 "Sant'Arcangelo"; ISPRA: Ispra, Italy, 2005.

43. Pieri, P.; Sabato, L.; Loiacono, F.; Marino, M. Il bacino di piggy-back di Sant'Arcangelo: Evoluzione tettonico-sedimentaria. Boll. Soc. Geol. It. 1994, 113, 465-481.

44. Caputo, R.; Bianca, M.; D'Onofrio, R. Ionian marine terraces of southern Italy: Insights into the Quaternary tectonic evolution of the area. Tectonics 2010, 29, TC4005. [CrossRef]

45. De Santis, V.; Caldara, M.; Torres, T.; Ortiz, J.E.; Sánchez-Palencia, Y. A review of MIS 7 and MIS 5 terrace deposits along the gulf of Taranto based on new stratigraphic and cronological data. Ital. J. Geosci. 2018, 137, 349-368. [CrossRef]

46. Santoro, E.; Ferranti, L.; Burrato, P.; Mazzella, M.E.; Monaco, C. Deformed Pleistocene marine terraces along the Ionian Sea margin of southern Italy: Unveiling blind fault-related folds contribution to coastal uplift. Tectonics 2013, 32, 737-762. [CrossRef] 
47. Westaway, R.; Bridgland, D. Late Cenozoic uplift of southern Italy deduced from fluvial and marine sediments: Coupling between surface processes and lower-crustal flow. Quat. Int. 2007, 175, 86-124. [CrossRef]

48. De Santis, F.; Giannossi, M.L.; Medici, L.; Summa, V.; Tateo, F. Impact of physico-chemical soil properties on erosion features in the Aliano area (Southern Italy). Catena 2010, 81, 172-181. [CrossRef]

49. Gallart, F.; Marignani, M.; Pérez-Gallego, N.; Santi, E.; Maccherini, S. Thirty years of studies on badlands, from physical to vegetational approaches. A succinct review. Catena 2013, 106, 4-11. [CrossRef]

50. Piccarreta, M.; Pasini, A.; Capolongo, D.; Lazzari, M. Changes in daily precipitation extremes in the Mediterranean from 1951 to 2010: The Basilicata region, southern Italy. Int. J. Climatol. 2013, 33, 3229-3248. [CrossRef]

51. Hiremagalur, J.; Yen, K.S.; Akin, K.; Bui, T.; Lasky, T.A. Creating standards and specifications for the use of laser scanning in caltrans projects. In AHMCT Research Report UDC-ARR-07-06-30-01; The National Academies of Sciences, Engineering, and Medicine: Washington, DC, USA, 2007; p. 93.

52. Leica Geosystems. Available online: http:/ /leica-geosystems.com/hds/ (accessed on 20 May 2019).

53. Girardeau-Montaut, D. Cloud Compare (Version 2.9): 3D Point Cloud and Mesh Processing Software Open Source Project. EDF R\&D, Telecom ParisTech 2015. Available online: http://www.danielgm.net/cc/ (accessed on 12 December 2018).

54. Brodu, N.; Lague, D. 3D terrestrial lidar data classification of complex natural scenes using a multi-scale dimensionality criterion: Applications in geomorphology. ISPRS J. Photogramm. Remote Sens. 2012, 68, 121-134. [CrossRef]

55. Lague, D.; Brodu, N.; Leroux, J. Accurate 3D comparison of complex topography with terrestrial laser scanner: Application to the Rangitikei canyon (N-Z). ISPRS J. Photogramm. Remote Sens. 2013, 82, 10-26. [CrossRef]

56. World Meteorological Organization. Guide to Instruments and Methods of Observation; World Meteorological Organization: Geneva, Switzerland, 2018; p. 548.

57. Foulds, S.A.; Warburton, J. Significance of wind-driven rain (wind-splash) in the erosion of blanket peat. Geomorphology 2007, 83, 183-192. [CrossRef]

58. Boenzi, F.; Palmentola, G.; Valduga, A. Note Illustrative della Carta Geologica D’Italia alla Scala 1:100000, Foglio 201 Matera. Sevizio Geologico d'Italia, 1971; p. 48.

59. Nadal-Romero, E.; Regüés, D.; Martí-Bono, C.; Serrano-Muela, P. Badland dynamics in the Central Pyrenees: Temporal and spatial patterns of weathering processes. Earth Surf. Process. Landf. 2007, 32, 888-904. [CrossRef]

60. Yair, A.; Goldshleger, N.; Kasanin-Grubin, M. Clay dispersion: An important factor in channel runoff generation in a semi-arid, loess-covered area with very low rain intensities. Geomorphology 2018, 320, 179-186. [CrossRef]

61. Erpul, G.; Norton, L.D.; Gabriels, D. Sediment transport from interrill areas under wind-driven rain. J. Hydrol. 2003, $276,184-197$. [CrossRef]

62. Solé-Benet, A.; Calvo, A.; Cerda, A.; Laćzaro, R.; Pini, R.; Barbero, J. Influences of micro-relief patterns and plant cover on runoff related processes in badlands from Tabernas (SE Spain). Catena 1997, 31, 23-38. [CrossRef]

63. Descroix, L.; Mathys, N. Processes, spatio-temporal factors and measurements of current erosion in the French southern Alps: A review. Earth Surf. Process. Landf. 2003, 28, 993-1011. [CrossRef]

64. Nadal-Romero, E.; Martínez-Murillo, J.F.; Vanmaercke, M.; Poesen, J. Scale-dependency of sediment yield from badland areas in Mediterranean environments. Prog. Phys. Geogr. 2011, 35, 297-332. [CrossRef]

65. Nearing, M.A.; Yin, S.Q.; Borrelli, P.; Polyakov, V.O. Rainfall erosivity: An historical review. Catena 2017, 157, 357-362. [CrossRef]

66. Erpul, G.; Norton, L.D.; Gabriels, D. Splash-saltation trajectories of soil particles under wind-driven rain. Geomorphology 2004, 59, 31-42. [CrossRef]

67. Niacsu, L.; Sfica, L.; Ursu, A.; Ichim, P.; Bobric, D.E.; Breaban, I.G. Wind erosion on arable lands, associated with extreme blizzard conditions within the hilly area of Eastern Romania. Environ. Res. 2019, 169, 86-101. [CrossRef] [PubMed] 